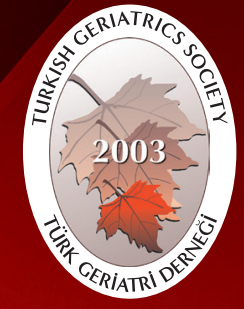

Turkish Journal of Geriatrics DOI: $10.31086 /$ tjgeri.2019.115 2019; 22(3): 376-383

- Hacer GÖK UĞUR ${ }^{1}$ D - Ayla HENDEKCi ${ }^{2}$ iD

\section{EFFECT OF PLANNED TRAINING PROVIDED TO CARE STAFF IN NURSING HOMES ON THEIR ATTITUDES TOWARD THE ELDERLY}

\section{Abstract}

Introduction: The aim of this study was to determine the effect of planned training provided to care staff in nursing homes on their attitudes toward the elderly.

Materials and Method: The study was conducted between July and September 2018 using the one-group, pre-test-post-test trial model and quasi-experimental study design. The study population comprised 45 care staff members in only one nursing home, and the study sample comprised 38 care staff members. Data were collected through the Information Form, Attitude toward Old People Scale, and Ageism Attitude Scale. Necessary ethical approval and permissions for the study were obtained. Care staff members were provided planned training 3 days per week for a month, and the effectiveness of the training was evaluated pre- and post-test.

Results: There was a statistically significant difference between the pre- and post-test mean scores of the Attitude toward Old People Scale and Ageism Attitude Scale (Restricting Life of the Elderly, and Positive Ageism and Negative Ageism subscales) $(p<0.05)$.

Conclusion: Planned training provided to care staff positively affected their attitudes toward the elderly and ageism. These results indicate that establishing a planned training program for care staff in a nursing home is important in terms of the quality of care they provide.

Keywords: Nursing home; Nursing staff; Education; Aged

ARAŞTIRMA

\section{Hacer GÖK UĞUR}

Ordu University Faculty of Health Sciences,

Department of Nursing, Altınordu/ORDU, Turkey.

Phone: +904522265200

Mobile: +905053767410

e-mail: hacer32@gmail.com

\section{Received: 14/03/2019}

Accepted: 22/08/2019

Ordu University Faculty of Health Sciences, Department of Nursing, Altınordu/Ordu, Turkey

Giresun University Faculty of Health Sciences, Department of Nursing, Piraziz/Giresun, Turkey.

\section{HUZUREVINDE ÇALIŞAN BAKIM PERSONELLERINE VERILEN PLANLI EĞITIMIN YAŞLILARA KARŞI TUTUMLARINA ETKISI Öz $_{z}$}

Giriş: Bu çalışma huzurevinde çalışan bakım personellerine verilen planlı eğitimin yaşıllara karşı tutumlarına etkisini belirlemek amacıyla yapıımıştır.

Gereç ve Yöntem: Araştırma tek grup ön test-son test deneme modeli ile yarı deneysel olarak sadece bir Huzurevi'nde çalışan bakım personelleri üzerinde, Temmuz-Eylül 2018 tarihleri arasında yürütülmüştür. Araştırmanın evrenini huzurevinde çalışan $\mathrm{N}=45$ bakım personeli, örneklemi ise 38 bakım personeli oluşturmuştur. Araştırmanın verileri; Bilgi Formu, Yaşılara Karşı Tutum Ölçeği ve Yaşı Ayrımcılığı Tutum Ölçeği ile toplanmıştır. Araştırma için gerekli etik onay ve izinler alınmıştır. Bakım personellerine 1 ay boyunca haftada 3 gün planlı eğitim yapılmış ve eğitimin etkinliği ön test-son test ile belirlenmiştir.

Bulgular: Araştırmada bakım personellerinin Yaşılıara Karşı Tutum Ölçeği ve Yaşlı Ayrımcılığı Tutum Ölçeği ile Yaşııın Yaşamını Sınırlama, Yaşlıya Yönelik Olumlu Ayrımcılık ve Yaşıya Yönelik Olumsuz Ayrımcılık alt boyutlarının ön test son test puan ortalamaları arasında istatistiksel olarak anlamlı bir farklılık olduğu bulunmuştur $(p<0.05)$.

Sonuç: Araştırmada bakım personellerine verilen planlı eğitimin, bakım personellerinin yaşılara karşı tutumlarını ve yaşlı ayrımcılığı tutumlarını olumlu yönde etkilediği belirlenmiştir. Bu sonuçlar doğrultusunda; huzurevinde çalışan bakım personellerine planlı eğitimlerin yapılması verecekleri bakımın kalitesi açısından önemli olacaktır.

Anahtar sözcükler: Huzurevi; Bakım personeli; Eğitim; Yaşlı 


\section{INTRODUCTION}

IThe elderly population has been increasing in the world as well as in Turkey (1). According to the Turkish Statistical Institute data, the elderly population in Turkey has increased by $17 \%$ in the last five years from 5.891 .694 in 2013 to 6.895 .385 in 2017 (2). These data indicate that elderly health and healthcare services for the elderly are an important issue in Turkey $(1,3)$. As the number of elderly people and diseases specific to old age increase, it is becoming increasingly difficult for family members to provide care for the elderly due to changes in social structure in recent years $(4,5)$. Therefore, care institutions are increasingly relied upon under present-day circumstances to meet the needs of elderly people with various health problems and those who require care (4). Elderly people living in nursing homes are cared for by the care staff members who assume many responsibilities while caring for the elderly (6). Typically, care staff members around the world undergo basic training in health, home management, human relations, and social services and receive in-service training and undergo supervision regularly. Since this is a newly developing field in Turkey, the training and background of the care staff are not at the desired levels $(3,7)$. Therefore, the approach of care staff toward the elderly may be variable. Attitudes of care staff toward the elderly are very important for the effectiveness of care they provide (8). Studies have shown that the attitudes of care staff toward the elderly also affect their care behaviors $(9,10)$. Therefore, drawing attention to the issue of aging among those providing care to the elderly and raising their awareness on this issue are important in terms of developing their positive attitude toward the elderly $(11,12)$. To this end, it is important to increase the awareness and capacity of care staff by providing planned training $(13,14)$. Indeed, the lack of information among care staff affects their attitudes toward the elderly (15). Therefore, the present study was conducted to determine the effect of planned training provided to care staff on their attitudes toward the elderly.

\section{Study Hypothesis}

HO: Planned training provided to care staff in a nursing home does not affect their attitudes toward the elderly.

H1: Planned training provided to care staff in a nursing home positively affects their attitudes toward the elderly and ageism.

\section{MATERIALS AND METHODS}

The study was conducted between July and September 2018 using the one-group, pre-testpost-test trial model and quasi-experimental study design. Care staff are the people who support elderly care in nursing homes but they are not health care professionals; they are trained about elderly care by Public Education Centers for 560 hours. The study population comprised 45 care staff members in only one nursing home, and the study sample comprised 38 care staff members who were actively working during the study period, who consented to communication and collaboration, who volunteered to participate in the study, and who regularly attended the training activities. Prior to the study, written permission, ethics approval, and written and verbal consents were obtained from the care staff.

\section{Data Collection Tools}

Data were collected using the Information Form, Attitude Toward Old People Scale, and Ageism Attitude Scale.

Information Form: This form was prepared by the researchers according to the literature and included nine questions regarding sociodemographic characteristics of the care staff $(4,10,16)$.

Attitude toward Old People Scale: The scale was developed by Nathan Kogan to measure attitudes of individuals toward the elderly. The scale comprises 34 items, with 17 of them being negatively worded and 17 being positively worded. 
Questions with an odd number are negatively worded, while questions with an even number are positively worded. All points are summed up to determine the total score (17). The version of the scale used in this study was a 26-item form adapted to the Turkish society. For items from 1 to 26 , the total score that can be obtained on the scale is a minimum of 26 and a maximum of 156 . A higher total score indicates a positive attitude toward the elderly (18).

Ageism Attitude Scale: The scale developed by Vefikuluçay and Terzioğlu comprises and 23 items across 3 subscales, including the Restricting Life of the Elderly, Positive Ageism, and Negative Ageism subscales. It is a 5-point Likert scale, with the multiple choices including "Strongly disagree," "Disagree," "Neither agree nor disagree," "Agree," and "Strongly agree" for each item pertaining to the elderly. The highest attainable score is "115," while the lowest possible score is "23" (19).

\section{Data Collection}

Data were collected through face-to-face interviews conducted by the researchers. Pre- and post-test data collection forms were administered to the care staff in the conference room of the nursing home for approximately 15-20 minutes.

\section{Training Program}

Training activities for the care staff were conducted 3 days per week (Monday, Wednesday, and Friday) for a month $(20,21)$. The topics of the training were planned according to the literature and were grouped under 10 headings $(13,22)$. The training activities were conducted in a multipurpose hall in the nursing home for a total of 12 hours (1 hour per day; 3:00-4:00 PM). The training activities were implemented using power point presentations and interactive training methods.

\section{Data Analysis}

Data were analyzed using SPSS 20.0 package software. Descriptive statistics, independent samples t-test, variance analysis, correlation test, and paired t-test were used to analyze data. The level of statistical significance was set at $p=0.05$.

\section{RESULTS}

In this section the results of the present study conducted to determine the effect of planned training provided to care staff in only one nursing home on their attitudes toward the elderly. Mean age of the care staff was $41.00 \pm 7.89$ years, and mean work experience were $8.26 \pm 5.58$. Overall, $71.1 \%$ of the care staff members were female, $86.8 \%$ were married, $50 \%$ were high school graduates, $57.9 \%$ had lived the longest in cities, $65.8 \%$ had a middle income, $65.8 \%$ lived in a nuclear family, and $76.3 \%$ lived with the elderly (Table 1).

Age of the care staff was significantly correlated to the scores of the Positive Ageism and Negative Ageism subscales of the Ageism Attitude Scale $(r=-0.398 ; p<0.05)$ (Table 2). Moreover, sex of the care staff was significantly correlated to the score of the Restricting Life of the Elderly subscale of the Ageism Attitude Scale $(t=2.491 ; p<0.05)$ (Table 2).

Moreover, the pre- and post-test scores of the Attitudes Toward Old People Scale and the Restricting Life of the Elderly, Positive Ageism, and Negative Ageism subscales of the Ageism Attitude Scale were significantly different ( $p<$ 0.05) (Table 3).

\section{DISCUSSION}

The attitudes of care staff members-who are important in today's society-toward the elderly are important for the quality of care they provide (9). The findings of this study indicated that the age of the care staff affected their attitude toward ageism. As the age of the care staff increases, their positive attitudes toward ageism decrease. In addition, sex of the care staff affected their attitudes, as determined by the Restricting Life 
Table 1. Sociodemographic characteristics of the care staff participating in the training.

\begin{tabular}{|c|c|c|c|}
\hline \multicolumn{2}{|l|}{ Characteristics } & \multicolumn{2}{|r|}{ Mean \pm SD (Range) } \\
\hline \multicolumn{2}{|l|}{ Age (years) } & \multicolumn{2}{|r|}{$41.00 \pm 7.89(23-56)$} \\
\hline \multicolumn{2}{|l|}{ Work experience } & \multicolumn{2}{|r|}{$8.26 \pm 5.58(2-21)$} \\
\hline & & $\mathrm{N}$ & $\%$ \\
\hline \multirow{2}{*}{ Sex } & Female & 27 & 71.1 \\
\hline & Male & 11 & 28.9 \\
\hline \multirow{2}{*}{ Marital status } & Married & 33 & 86.8 \\
\hline & Single & 5 & 13.2 \\
\hline \multirow{5}{*}{ Educational background } & Primary school & 4 & 10.5 \\
\hline & Secondary school & 10 & 26.3 \\
\hline & High school & 19 & 50.0 \\
\hline & Undergraduate & 2 & 5.3 \\
\hline & Graduate & 3 & 7.9 \\
\hline \multirow{3}{*}{ Longest residence } & Village & 12 & 31.6 \\
\hline & District & 4 & 10.5 \\
\hline & City & 22 & 57.9 \\
\hline \multirow{3}{*}{ Income level } & Low & 2 & 5.3 \\
\hline & Middle & 25 & 65.8 \\
\hline & High & 11 & 28.9 \\
\hline \multirow{2}{*}{ Family type } & Nuclear & 25 & 65.8 \\
\hline & Extended & 13 & 34.2 \\
\hline \multirow{2}{*}{ Living with the elderly } & Yes & 29 & 76.3 \\
\hline & & 9 & 23.7 \\
\hline \multicolumn{2}{|l|}{ Total } & 38 & 100.0 \\
\hline
\end{tabular}

B, Regression coefficient; SE, Standard error; $\beta$, Beta value; $\mathrm{Cl}$, Confidence interval; AChE. Acetylcholinesterase; 25(OH)D, 25-hydroxyvitamin D ${ }^{*} \mathrm{P}$ value $<0.05,{ }^{* *} \mathrm{P}$ value $<0.01$ 
of the Elderly subscale of the Ageism Attitude Scale; female members of the care staff exhibited a more positive attitude. In addition, marital status, educational background, the place of the longest residence, income level, type of family, work experience, and age of the care staff did not affect their ageism attitude. Pekçetin has found that sociodemographic characteristics of the care staff do not affect their attitudes toward aging (16). Meanwhile, Bulut and Çilingir have described that educational background of surgical nurses affects their attitude toward aging (10). In our study, the association of age and sex of the care staff with their attitudes toward ageism was attributed to the facts that as the age of the care staff increases, their ability to cope with the elderly decreases and that care is considered a duty of women in our social structure. In a systematic review, Neville and Dickie have reported that the attitude toward the elderly is affected by age, sex, education, culture, institutional characteristics, and personality of the employee (9). In contrast, Ayaz Alkaya et al. (11) have stated that living at home with elderly people and providing care to elderly family members affect the attitudes toward the elderly. In addition, Ucun et al. (23) have stated that sociodemographic characteristics of young people do not affect their attitudes toward older individuals. Our findings indicate that the attitudes of the care staff towards the elderly was affected according to their sociodemographic variables - specifically age and sex.

In this study, there was statistically significant difference between pre- and post-test mean scores of the Attitudes toward Old People Scale and Ageism Attitude Scale. Moreover, the attitudes of the care staff toward the elderly and ageism, which were moderate pre-test, positively changed with the planned training. Similarly, Lee et al. (24) have stated that attitudes toward the elderly can positively change with education. In a singlegroup, pre-test-post-test study conducted by
Baumbusch et al. (21) a 4-week training program for nursing students positively affected their knowledge of and attitudes toward the elderly. Rodgers and Gilmour have reported that the training provided to nursing students regarding the elderly showed a positive effect on their attitudes toward older people (25). In addition, in a study of care staff in nursing homes, Board et al. (20) have stated that the training program on dementia positively affected knowledge and attitudes of the participants. The present study showed the attitudes and knowledge of included care staff changed positively, which is consistent with the literature.

Nonetheless, this study has two major limitations. First, the results can only be generalized to this particular group since the research was conducted including care staff in a single nursing home. Second, since there was only one nursing home in the province where the study was conducted and the number of employees was low, the single-group, pre-test-post-test trial model was used, and no control group was included.

\section{CONCLUSION AND RECOMMENDATIONS}

In this study, planned training provided to care staff in a nursing home positively affected their attitudes toward the elderly and ageism. Our results indicate that supporting the care staff members who are becoming increasingly important as they provide care to the growing population of the elderly by establishing training programs on different aspects at regular intervals is imperative in terms of the quality of care they provide. Nonetheless, similar studies should be conducted including large cohorts of care staff members working in different nursing homes and institutions as well as a control groups using post-test follow-up models to monitor changes in attitudes. 
Table 2. Mean Attitudes toward Old People and Ageism Scale Scores by Participant Sociodemographic Characteristics

\begin{tabular}{|c|c|c|c|c|c|c|}
\hline \multirow{2}{*}{\multicolumn{2}{|c|}{ Characteristics }} & \multirow{2}{*}{$\begin{array}{l}\text { Attitude Toward } \\
\text { Old People Scale }\end{array}$} & \multirow{2}{*}{$\begin{array}{r}\text { Ageism Attitude } \\
\text { Scale }\end{array}$} & \multicolumn{3}{|c|}{ Ageism Attitude Subscales } \\
\hline & & & & $\begin{array}{l}\text { Restricting Life } \\
\text { of the Elderly }\end{array}$ & Positive Ageism & $\begin{array}{r}\text { Negative } \\
\text { Ageism }\end{array}$ \\
\hline \multicolumn{2}{|l|}{ Age (years) } & $41.00 \pm 7.89$ & $41.00 \pm 7.89$ & $41.00 \pm 7.89$ & $41.00 \pm 7.89$ & $41.00 \pm 7.89$ \\
\hline \multicolumn{2}{|l|}{ Test/P } & $r=0.108 / p=0.517$ & $r=-0.398 * / p=0.013$ & $r=-0.134 / p=0.421$ & $r=-0.393^{\star} / p=0.015$ & $r=-0.323 \star / p=0.048$ \\
\hline \multicolumn{2}{|c|}{ Work experience } & $8.26 \pm 5.58$ & $8.26 \pm 5.58$ & $8.26 \pm 5.58$ & $8.26 \pm 5.58$ & $8.26 \pm 5.58$ \\
\hline \multicolumn{2}{|l|}{ Test/P } & $r=-0.056 / p=0.739$ & $r=-0.195 / p=0.240$ & $r=-0.158 / p=0.343$ & $r=-0.153 / p=0.358$ & $r=-0.240 / p=0.147$ \\
\hline \multirow{2}{*}{ Sex } & Female & $78.48 \pm 10.23$ & $17.56 \pm 3.34$ & $26.85 \pm 4.84$ & $11.56 \pm 1.89$ & $57.41 \pm 7.75$ \\
\hline & Male & $77.00 \pm 9.24$ & $15.45 \pm 1.81$ & $28.00 \pm 5.37$ & $10.36 \pm 1.96$ & $56.27 \pm 7.82$ \\
\hline \multicolumn{2}{|l|}{ Test/P } & $\mathrm{t}=0.416 / \mathrm{p}=0.680$ & $\mathrm{t}=.408 / \mathrm{p}=0.685$ & $\mathrm{t}=2.491 / \mathrm{p}=0.018$ & $\mathrm{t}=-0.643 / \mathrm{p}=0.524$ & $\mathrm{t}=1.745 / \mathrm{p}=0.089$ \\
\hline \multirow{2}{*}{ Marital status } & Married & $77.73 \pm 10.38$ & $16.67 \pm 3.06$ & $26.76 \pm 5.03$ & $11.12 \pm 2.09$ & $56.36 \pm 7.92$ \\
\hline & Single & $80.20 \pm 5.36$ & $18.80 \pm 3.11$ & $30.00 \pm 3.67$ & $11.80 \pm 0.45$ & $61.80 \pm 3.42$ \\
\hline \multicolumn{2}{|l|}{ Test/P } & $t=-0.518 / p=0.608$ & $\mathrm{t}=-1.500 / \mathrm{p}=0.142$ & $\mathrm{t}=-1.450 / \mathrm{p}=0.156$ & $t=-1.381 / p=0.176$ & $t=-0.716 / p=0.478$ \\
\hline \multirow{5}{*}{$\begin{array}{l}\text { Educational } \\
\text { background }\end{array}$} & Primary school & $85.75 \pm 7.27$ & $16.75 \pm 1.89$ & $25.00 \pm 3.56$ & $10.25 \pm 0.96$ & $53.00 \pm 2.94$ \\
\hline & $\begin{array}{l}\text { Secondary } \\
\text { school }\end{array}$ & $78.40 \pm 9.90$ & $16.90 \pm 4.36$ & $27.20 \pm 5.09$ & $11.20 \pm 2.25$ & $56.40 \pm 8.67$ \\
\hline & High school & $74.63 \pm 10.19$ & $17.11 \pm 2.96$ & $26.84 \pm 5.35$ & $11.42 \pm 2.14$ & $57.47 \pm 8.37$ \\
\hline & Undergraduate & $86.00 \pm 1.41$ & $18.50 \pm 2.12$ & $31.50 \pm 0.71$ & $11.50 \pm 0.71$ & $63.50 \pm 2.12$ \\
\hline & Graduate & $83.00 \pm 3.00$ & $15.33 \pm 0.58$ & $29.33 \pm 4.93$ & $11.00 \pm 1.73$ & $58.00 \pm 5.29$ \\
\hline \multicolumn{2}{|l|}{ Test/P } & $F=1.858 / p=0.141$ & $F=0.649 / p=0.632$ & $F=0.318 / p=0.864$ & $F=0.715 / p=0.588$ & $F=0.290 / p=0.882$ \\
\hline \multirow{3}{*}{$\begin{array}{l}\text { The longest } \\
\text { residential } \\
\text { place }\end{array}$} & Village & $78.75 \pm 10.92$ & $16.58 \pm 3.26$ & $27.67 \pm 5.60$ & $11.50 \pm 2.11$ & $57.75 \pm 8.62$ \\
\hline & District & $73.50 \pm 10.54$ & $17.25 \pm 4.79$ & $26.25 \pm 2.36$ & $11.25 \pm 2.50$ & $56.50 \pm 6.95$ \\
\hline & City & $78.50 \pm 9.39$ & $17.09 \pm 2.84$ & $27.09 \pm 5.07$ & $11.05 \pm 1.86$ & $56.82 \pm 7.59$ \\
\hline \multicolumn{2}{|l|}{ Test/P } & $F=0.466 / p=0.631$ & $F=0.066 / p=0.936$ & $F=0.119 / p=0.888$ & $F=0.126 / p=0.882$ & $F=0.200 / p=0.819$ \\
\hline \multirow{3}{*}{ Income level } & Low & $77.00 \pm 14.14$ & $17.50 \pm 3.54$ & $22.50 \pm 12.02$ & $10.50 \pm 0.71$ & $50.50 \pm 16.26$ \\
\hline & Middle & $76.72 \pm 10.99$ & $16.56 \pm 3.29$ & $26.68 \pm 4.94$ & $11.16 \pm 2.15$ & $56.48 \pm 8.02$ \\
\hline & High & $81.27 \pm 5.76$ & $17.73 \pm 2.72$ & $29.18 \pm 2.89$ & $11.45 \pm 1.69$ & $59.64 \pm 4.54$ \\
\hline \multicolumn{2}{|l|}{ Test/P } & $F=0.819 / p=0.499$ & $F=1.454 / p=0.247$ & $F=0.558 / p=0.578$ & $F=2.025 / p=0.147$ & $F=0.215 / p=0.807$ \\
\hline \multirow{2}{*}{ Family type } & Nuclear & $77.40 \pm 10.30$ & $17.36 \pm 3.00$ & $26.24 \pm 4.88$ & $11.28 \pm 2.03$ & $56.56 \pm 7.64$ \\
\hline & Extended & $79.31 \pm 9.19$ & $16.15 \pm 3.29$ & $29.00 \pm 4.74$ & $11.08 \pm 1.89$ & $58.08 \pm 7.96$ \\
\hline \multicolumn{2}{|l|}{ Test/P } & $\mathrm{t}=-0.561 / \mathrm{p}=0.578$ & $\mathrm{t}=0.572 / \mathrm{p}=0.571$ & $t=1.139 / p=0.262$ & $\mathrm{t}=-1.668 / \mathrm{p}=0.104$ & $\mathrm{t}=0.299 / \mathrm{p}=0.767$ \\
\hline \multirow{2}{*}{$\begin{array}{l}\text { Living with } \\
\text { the elderly }\end{array}$} & Yes & $78.10 \pm 8.93$ & $16.62 \pm 2.81$ & $27.55 \pm 4.72$ & $11.03 \pm 1.82$ & $56.97 \pm 7.32$ \\
\hline & No & $77.89 \pm 13.04$ & $18.00 \pm 3.94$ & $26.00 \pm 5.79$ & $11.78 \pm 2.39$ & $57.44 \pm 9.22$ \\
\hline \multicolumn{2}{|l|}{ Test/P } & $\mathrm{t}=0.056 / \mathrm{p}=0.955$ & $\mathrm{t}=0.161 / \mathrm{p}=0.873$ & $\mathrm{t}=-1.168 / \mathrm{p}=0.250$ & $\mathrm{t}=0.817 / \mathrm{p}=0.419$ & $t=0.993 / p=0.327$ \\
\hline
\end{tabular}

$\mathrm{t}=$ Independent samples $\mathrm{t}$-test, $\mathrm{F}=$ Variance analysis, $\mathrm{r}={ }^{*}$. Correlation is significant at the 0.05 level ${ }^{\star} \mathrm{P}$ value $<0.05,{ }^{* *} \mathrm{P}$ value $<0.01$ 
Table 3. Regression coefficients of multiple linear regression in the second step.

\begin{tabular}{|l|r|r|r|r|}
\hline & Pre-test & Post-test & Test & P value \\
\cline { 2 - 5 } & Mean \pm SD & Mean \pm SD & & \\
\hline Attitudes Toward Old People Scale & $78.05 \pm 9.85$ & $81.58 \pm 9.34$ & $\mathrm{t}=-3.682$ & 0.001 \\
\hline Restricting Life of the Elderly & $16.95 \pm 3.11$ & $19.71 \pm 2.79$ & $\mathrm{t}=-5.563$ & 0.000 \\
\hline Positive Ageism & $27.18 \pm 4.95$ & $30.92 \pm 6.04$ & $\mathrm{t}=-6.859$ & 0.000 \\
\hline Negative Ageism & $11.21 \pm 1.96$ & $12.45 \pm 2.02$ & $\mathrm{t}=-3.751$ & 0.001 \\
\hline Ageism Attitude Scale & $57.08 \pm 7.68$ & $61.34 \pm 6.72$ & $\mathrm{t}=-6.179$ & 0.000 \\
\hline $\mathrm{t}=$ paired t-test & & & \\
\hline
\end{tabular}

\section{REFERENCES}

1. Turaman C. Planning elderly care at the basic level of health services. Turkish Journal of Geriatrics 2001;4(1):22-7.

2. Turkish Statistical Institute. Elderly with statistics. [Internet] Available from: https://www. brandingturkiye.com/tuikten-istatistiklerle-yaslilarraporu-2018/. Accessed:15.03.2018.

3. Danış MZ, Genç Y. General characteristics and problems of institutional care staff. Yalova University Journal of Social Sciences 2011;1(2):170-83.

4. Aközer M, Nuhrat C, Say Ş. Expectations regarding old age in Turkey. Journal of Social Policy Studies 2011;12(7):103-28.

5. Işık $O$, Kandemir A, Erişen MA, et al. Profile of patients who use home care health services and evaluation of provided service. Hacettepe Health Administration Journal 2016;19(2):171-86.

6. Kulakçı H, Emiroğlu ON. The usability of the Omaha system in identifying the health needs, nursing interventions and outcomes of the elderly living in a nursing home. Hacettepe University Faculty of Health Sciences Nursing Journal 2012;19(1):36-50.

7. Oğlak S. The value of informal caregiving on elderly care: as a shadow workforce. IGUJSS 2017;4(2):73-87. https://dx.doi.org/10.17336/igusbd.348785.

8. Kalınkara $V$, Kalaycı I. Work load, fatigue and burnout relationship between the health personnel. JESD 2018;6(Special Issue):125-36. doi:10.21923/ jesd.369346.
9. Neville C, Dickie R. The evaluation of undergraduate nurses' attitudes, perspectives and perceptions toward older people. Nurse Educ Today 2014;34(7):1074-9. (PMID: 24815180).

10. Bulut $E$, Çilingir D. Attitudes of surgical nurses towards the elderly. Turkish Journal of Geriatrics 2016;19(4):253-9.

11. Ayaz Alkaya S, Birimoğlu Okuyan C. Nursing students' attitudes towards the elderly. Hacettepe University Faculty of Health Sciences Nursing Journal 2017;4(1):43-52.

12. Oyetunde MO, Ojo OO, Ojewale LY. Nurses' attitude towards the care of the elderly: implications for gerontological nursing training. J Nurs Educ Pract 2013;3(7):150-8. doi:10.5430/jnep.v3n7p150.

13. Adıbelli D, Türkoğlu N, Kılıç D. Determining critical thinking dispositions of nursing: a comperative study. DEUHEFED 2013;6(1):2-8.

14. R Uçku. Basic Information in Elderly Care, In: Arslantaş D (Ed). Elderly and Patient Care Services. 3rd Edition, Anadolu University, Publication No: 1462, Eskişehir 2012, pp 2-25.

15. Gülen $M$, Aktürk $A$, Acehan $S$, et al. Elder abuse and neglect. Archives Medical Review Journal 2013;22(3):393-407.

16. Pekçetin S. Ageist attitudes and their association with burnout and job satisfaction among nursing staff: a descriptive study. Turkish Journal of Geriatrics 2018;21(1):25-32. doi:10.31086/tjgeri.2018137963. 
17. Kogan N. Attitudes toward old people: the development of a scale and an examination of correlations. J Abnorm Psychol 1961;62:44-54. (PMID: 13757539).

18. Kılıç D, Adıbelli D. The validity and reliability of Kogan's attitude towards old people scale in the Turkish society. Health 2011;3(9):602-8. doi:10.4236/ health.2011.39101.

19. Vefikuluçay D, Terzioğlu F. Development and psychometric evaluation of ageism attitude among the university students. Turkish Journal of Geriatrics 2011;14:259-68.

20. Board M, Heaslip V, Fuggle K, et al. How education can improve care for residents with dementia. Nurs Older People 2012;24(5):29-31. (PMID: 22792698).

21. Baumbusch J, Dahlke S, Phinney A. Nursing students' knowledge and beliefs about care of older adults in a shifting context of nursing education. J Adv Nurs 2012;68(11):2550-8. (PMID: 22364192).

22. N Paksoy Erbaydar. Violence, Negligence and Abuse of Old Age Period, In: Bahar Özvarış Ş. Aslan D (Eds). Elderly Health Modules. Anıl Printery Inc, Ankara 2011, pp 401-11.

23. Ucun Y, Mersin S, Öksüz E. Attitudes towards elderly of young's. The Journal of International Social Research 2015;8(37):1143-9.

24. Lee YS, Shin SH, Greiner PA. Can education change attitudes toward aging? A quasi-experimental design with a comparison group. J Nurs Educ Pract 2015;5(9):90-9. doi:10.5430/jnep.v5n9p90.

25. Rodgers V, Gilmour J. Shaping student nurses' attitudes towards older people through learning and experience. Nurs Prax NZ 2011;27:13-20. (PMID: 22375376). 